\title{
Cold War Cosmopolitan Feminism
}

When Han Hyung-mo's film A Jealousy opened in May of 1960, it was the rare Korean film to focus on a female same-sex romantic relationship. The film explores the bond between Jaesoon (Moon Jung-suk), who lives with her brother and his family, and Kum (Jeon Gye-hyeon), a college student who has lived with them since losing her parents in the Korean War. Jaesoon and Kum are "S-sisters," which was the term used in Korea (and Japan) for an intimate, although not necessarily sexual, relationship between women. (The $S$ reportedly derived from either shojyo, the Japanese word for girl, or from sex.) Historically, these relationships began developing in Korea in the 1910s and 1920s in the new, modern spaces of missionary-run women's schools and colleges. ${ }^{1}$ These passionate relationships, which typically involved pairings of older and younger students or teachers and students, remained common in the postwar era and were understood to be distinct from those between best friends and adopted or sworn sisters. ${ }^{2}$ A Jealousy suggests a desire for, if not the fact of, physical intimacy when Jaesoon ( $S$ unni, or S-older sister) invites Kum (S tongsaeng, or S-younger sister) to spend the night in her bed, and Jaesoon's brother explicitly raises the issue of lesbianism. The film's dramatic conflict revolves around Jaesoon's increasing jealousy as a man begins to court Kum: the intensity of her feelings prompts both passionate declarations of love ('I'll love you until I die, Kum.... We're one body, a body that can't ever be separated") and acts of physical violence (she tries to strangle Kum in order to prevent her marriage) (figure 3). Narratively, A Jealousy delegitimizes Jaesoon's desire, presenting it as a form of mental illness caused by her experience of being raped during the Korean War and bookending the film with scenes in a hospital where Jaesoon has been committed and ultimately cured. 


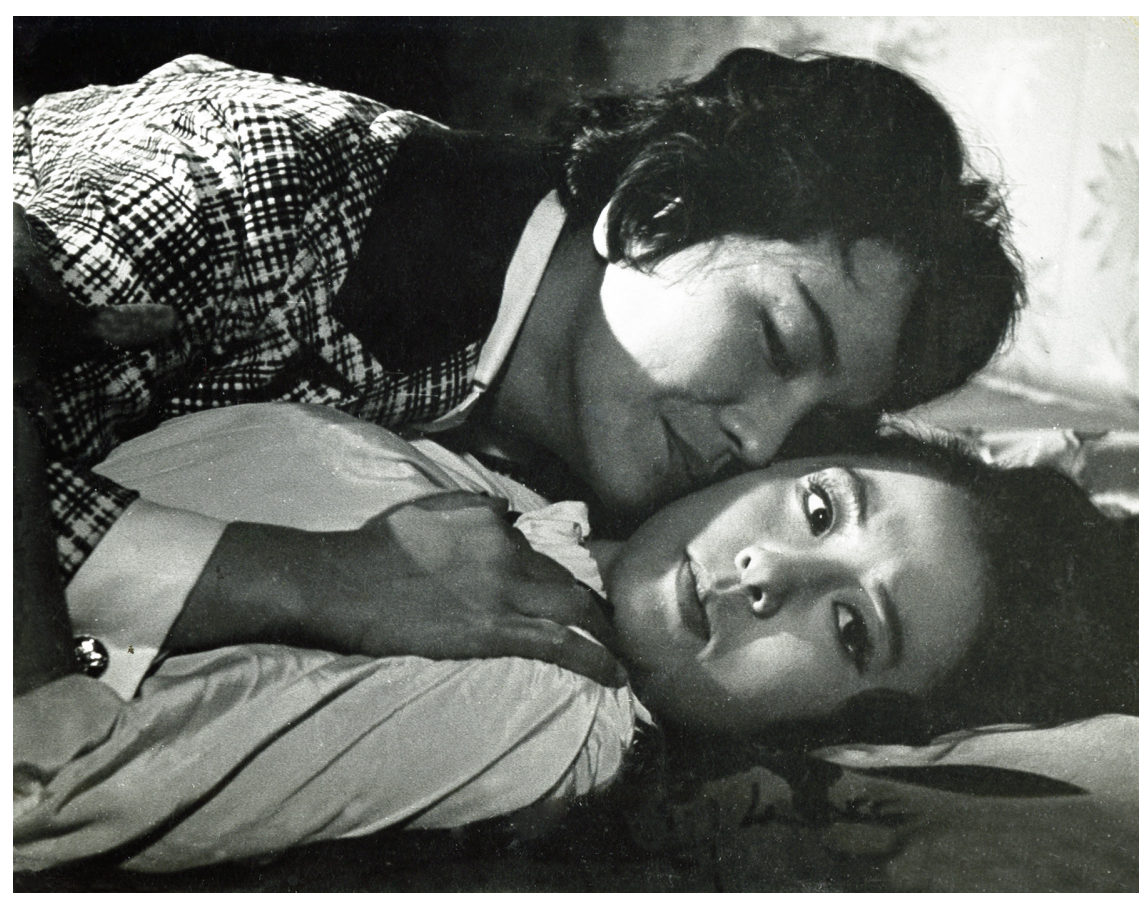

FIGURE 3. Moon Jung-suk and Jeon Gye-hyeon in Han Hyung-mo's lesbian drama A Jealousy. (Courtesy KOFA)

More important, perhaps, than the film's dismissal of lesbian desire is its forthright expression of feminist ideas. In her dialogue, Jaesoon critiques the patriarchal family as an institution of "slavery" for women and suggests that talented women should pursue careers instead of marriage-ideas that Korean feminists first raised in the 1920 and 1930 and were now expressing with increased authority. In one scene Jaesoon debates Kum's future with her brother, the head of the family, and proposes that Kum continue her musical training and become "a wonderful musician." When her brother suggests that Kum become a "wonderful housewife" instead, Jaesoon explodes: "That's all you can come up with? After all I've gone through to raise my darling Kum into a brilliant artist, do you really think it's right for her to become a slave of a family?" Jaesoon extends her critique of heterosexual marriage in subsequent scenes, when she sneers, "I just can't think it would make a woman happy to become a slave of a man and live only to serve him all day long," and later, "I can't give Kum to men who treat women like slaves and look down on them." Seeking to break with the Confucian past, Jaesoon aspires to save her beloved S-sister from the exploitation that has defined Korean women for generations: "I just can't have 
Kum suffer the same treatment our mothers and grandmothers received from men until now."3 Her proposed solution is to set up a separate household in which she and Kum live together, alone. It doesn't happen. While Jaesoon can envision new possibilities for women, she can't quite bring them into existence. ${ }^{4}$

In articulating these possibilities, A Jealousy gestures towards the tremendous changes taking place among women during the 1950s, as the postcolonial, postwar, and Cold War forces remaking Korean society reached deep into their daily lives. This chapter takes up social history, and traces how the ideals and practices of Cold War cosmopolitanism intersected with Korean women's lives. Women across the social spectrum, mostly urban, engaged with the Free World as it was manifest both within and beyond Korea's borders, and some of them absorbed its professed liberal values of democracy, equality, and freedom. One result was the articulation of a "Cold War cosmopolitan feminism," which sought to emancipate women from the patriarchal constraints of Korea's Confucian heritage by claiming for them the liberal ideal of individual freedom. The period also saw the articulation of a counter-discourse of patriarchal cultural nationalism, which identified some of those same traditions as the essence of a Koreanness that must be preserved against foreign encroachments. The tensions between cultural nationalism and cosmopolitanism, like those between nation building and bloc building, helped define the period out of which Han's style emerged.

\section{WOMEN AND SOCIAL MODERNITY}

In the postwar 1950s, American and Korean modernizers alike encouraged Korean women to craft broader lives for themselves. Modernity "understood as the birth of the individual," as Cho Haejoang writes, was promoted to women as well as men. In Korea as elsewhere in the developing world, the "emancipation of women" was often regarded as an essential step into modernity, a feminine corollary to the drive to "make men modern," and self-declared "modern" women pushed against what they regarded as the "feudal" patriarchal constraints embedded in Confucianism. 5 This push was often couched in the language of individualism, that core tenet of liberal thought and "one of the most difficult things to recognize, either ideologically or institutionally, in the Confucian tradition."6 "Individualism," according to Stevi Jackson, Jieyu Liu, and Juhyun Woo, has long been "problematic in East Asia. It is not universally embraced as the inalienable right of the sovereign individual, as in Western philosophy, but as something more troubling and full of contradictions" that threatens to disrupt a widely desired social harmony. ${ }^{7}$ Claims of female individuality were, as a result, often contested by self-proclaimed guardians of Korea's cultural identity. The "female individual" thus became an ambivalent incarnation of Korean modernity: she embodied ideals that were desired by some as a pathway into a better future, and feared by others as a threat to an essential Koreanness that was in the process of being restored in the wake of colonialism. 
Korea was home to the strictest form of Confucianism in East Asia, and while orthodox neo-Confucianism had been under attack in Korea since the late nineteenth century as an obstacle to modernization and the development of a national consciousness, its ideals still carried weight as the foundation for everyday life. ${ }^{8}$ This was nowhere more apparent than in the realm of gender and family relations. “The Confucian ethic," write Jackson et al.,

privileges order and hierarchy, the needs of the collective over those of the individual, filial piety and women's obedience to men. It thus leaves little scope for women's autonomy or for expressions of sexuality that are not harnessed to the needs of men and of procreation-especially the production of male children who will perpetuate the family. It has been described as "the most patriarchal of all the major normative systems of the world." 9

The principle of absolute sexual difference (namnyŏ-yubyŏl), for instance, historically consigned women to the inner quarters of the home and to the roles of wife and mother, while allotting to men the exterior rooms and the ability to enter the public sphere of business, education, and the law at will. The principle of "honored men, debased women" (namjon-yŏbi), in turn, dictated women's inferiority to men in all areas of life, while the principle of the "three obediences" (samjong) called for the submission of daughter to father, wife to husband, and widow to son. Selfdenial lay at the heart of the feminine virtues of submissiveness, chastity, modesty, and self-sacrifice. Together they rendered female suffering noble. After a woman's marriage, the interests of her husband's family became paramount. A wife was valued for her ability to produce male heirs to continue her husband's lineage and as a source of cheap household labor. Her most important relationship was with her mother-in-law, whom she was expected to serve unquestioningly; an emotionally close relationship with her husband was neither encouraged nor valued. Marriages were understood, however, to endure beyond the death of the husband, and widow remarriage was taboo. A woman who committed one of the "seven disobediences" (ch'ilgŏ)—which included disrespect to parents-in-law, failure to bear a son, and adultery-left herself vulnerable to divorce, which entailed losing all rights to her children. The ideal of "wise mother, good wife" (hyŏnmo yangch’ŏ) was a modern variation of these patriarchal ideals that incorporated elements of Christian missionary and Japanese colonial ideologies and focused on a woman's role within a nuclear family. ${ }^{10}$

Taken together, these Confucian principles restricted every dimension of a woman's life. Lacking even an individual name until the early twentieth century, a woman possessed no social identity outside of her family relationships and roles. Her space for autonomous action was severely constrained, both physically and socially. No respectable woman could live an independent existence, or establish an independent household, outside of a relationship to father, husband, or son. "According to Confucian ideology," writes Hyun Jeong Min, "a woman 
seeking to fulfill her aspirations could destroy the peace and harmony of the social world." ${ }^{11}$ Female submission served as the foundation for a smoothly functioning social order. The existence of a "female individual"-a woman in charge of her own life and in possession of a social identity separate from her familywas structurally impossible.

This ideal of womanhood was challenged by Christian missionaries beginning in the late nineteenth century and began to fray in the 1920 s and 1930 . The Korean modeon geol was a local incarnation of the global "modern girl" who emerged in the United States, Europe, Asia, and Africa after World War I and who represented that era's aspirations and anxieties about modernity. Dressed in Western fashion and embracing liberal Western ideas, she was a largely discursive figure who existed primarily in the pages of newspapers and magazines, where she raised the possibility of an autonomous female self and was lambasted as an irresponsible consumer. The New Woman was more firmly rooted in social reality. A small group of educated, urban, and often Christian young women, New Women were Korea's first-generation feminists who challenged Korea's patriarchal social order head-on. They articulated visions of female liberation that they sought to put into practice by creating women's social organizations, publishing women's magazines, and taking up professional careers. ${ }^{12}$

Confucian gender roles were further challenged by the enormous scale of death and injury during the Korean War, which hastened the evolution of women's roles and led to the emergence (mostly in Seoul) of what I am calling the "womanin-public" as a postwar social type. The social dislocations of the war propelled women in unprecedented numbers into the public sphere and into domains of life that had previously been the preserve of men. This process began when women were mobilized to replace the labor of the millions of men who were fighting. Women enlisted in the army, where they worked in administrative and support positions, and performed sexual labor in government-sanctioned "comfort houses" and dance halls. In the civilian labor force they worked as clerks, policewomen, factory laborers, and office ladies; nearly half a million women became small vendors, selling food and other necessities on the streets. ${ }^{13}$ In $1951-52$ about 60 percent of the female working-age population was engaged in labor, primarily in agriculture and fisheries, which marked a major increase over the 28.4 percent employment rate in $1949 .{ }^{14}$

While many of these women returned to their homes at the war's conclusion, in 195835 percent of the adult female population participated in the labor force, and women comprised 46 percent of the total economically active population. ${ }^{15}$ A greater variety of women worked than during the colonial era, including widows, older women, and some married women, alongside single young women. ${ }^{16}$ While most of these women had working-class and agricultural jobs, they also occupied a wider range of white-collar positions than in previous decades: the 1955 census counted 10,026 professional, managerial, and clerical workers in Seoul 
alone; five years later journalist Chung Choong-ryang reported a national tally of 777 female doctors, 1,407 pharmacists, 3,602 nurses, 3 members of the House of Representatives, 3 current and former cabinet ministers, 3 presidents of women's universities, and 1 attorney. ${ }^{17}$ Most women worked out of necessity, often taking on the role of breadwinner to support their parents, in-laws, and children following a male relative's wartime injury or death. Others, however, worked out of choice, seizing the opportunity to pursue a dream or achieve an unprecedented measure of personal autonomy. As Sujin Han has written, "the conspicuous presence of women in the public arena of work" was one of the defining features of the postwar period, and the working woman became a vigorous topic of debate, as intellectuals, officials, and workers themselves explored the implications of women's movement into public economic life. Women's work was often tinged with nationalist overtones in public discourse, especially during the war years, and numerous commentators presented women's entry into the work force as a sign of the country's modernization and democratization. Working women themselves often regarded paid employment as a recognition of their individuality and full humanity. ${ }^{18}$

The woman-in-public was also a product of the Cold War, which is to say that her emergence was deeply affected by the presence of tens of thousands of American soldiers inside the country. The work of sustaining this large population made the US military a major employer of Korean women. The US armed forces hired women to work on virtually every major post as maids, cooks, waitresses, dishwashers, receptionists, typists, secretaries, clerks, and cashiers. Many more women found work in the eighteen camptowns that ringed major military bases. Enabled and regulated by US military officials, camptowns were liminal contact zones composed of businesses that catered to GIs, such as bars, nightclubs, pool halls, and souvenir shops. Camptowns were important sites of economic activity that generated essential foreign exchange for use in other areas of the economy, and were thus tolerated and even encouraged by the ROK government. They were also what Seungsook Moon has called "virtually colonized spaces" in which US military authority superseded South Korean sovereignty. ${ }^{19}$ As numerous scholars have explored, camptowns generated a dark version of cosmopolitan modernity characterized by militarized prostitution. ${ }^{20}$ Driven by poverty, many Korean women found work in the booming sex trade, and in 1958, an estimated 180,000 sex workers-or more than half of Korea's estimated total of 300,000-catered to American soldiers. These women, often comparatively affluent, were among the first to embrace American fashions, learn English, and master Western social practices such as social dancing, and they served as vanguard agents who carried bits of Americanized modernity into Korean society at large. ${ }^{21}$ They also became potent symbols of the vast imbalance of power between the United States and Korea and of the pervasiveness of American hegemony. Frequent targets of American violence and Korean hostility, they contributed to the ambivalence many Koreans felt about the American presence inside their country. ${ }^{22}$ 
Women in South Korea and across the Free World were targeted by American agencies waging the cultural Cold War as a key demographic whose allegiance needed to be won (along with students, workers, intellectuals, and educated elites). The USIS, according to Kenneth Osgood, "drafted elaborate policy guidance papers" that focused on women and the theme of gender across media:

Women in positions to act as "channels for political information," including leaders, members of organizations, wives of important officials, and university students, were especially targeted. USIS posts devised a number of tactics to reach women directly. They presented books and magazines to women leaders and organizations, hosted special films for women, produced radio programs for female audiences, taught English classes for women, organized seminars and discussions with "outstanding American women," and prepared exhibits and events at USIS libraries and information centers designed to appeal to women. Information officers placed articles of interest to female readers in local newspapers and magazines. Special USIS mailing lists sent information material to women leaders of civic, political, and charitable organizations. Such efforts sought to "assure [foreign] women that American women have interests and goals in common with their own" and "to encourage on a basic human level an identification of the local woman with American women."

Through these efforts the USIS aimed to win the sympathies of women so that they, in turn, could exert pressure on their husbands and their governments "to act in ways commensurate with U.S. interests." ${ }^{23}$ The agency disseminated representations of modern American women across the Free World, projecting them as feminized-and thus nonthreatening-symbols of the United States and as objects of identification. In response to socialist promises of gender equality in a revolutionary society, it promoted a vision of women as both domestic denizens and active participants in public life. While the USIS emphasized that American women "lived full, happy lives as mothers and homemakers," it also depicted American women as playing "an increasingly important part in political, economic, and community life." USIS materials portrayed women as community activists involved in clubs and civic organizations and highlighted their status as professionals, noting women's advancement in fields formerly reserved for men. It singled out "outstanding women" who served as congresswomen, senators, state legislators, governors, and presidential cabinet members. ${ }^{24}$ Such representations were widely distributed in Korea where, in 1961, USIS films screened in threequarters of all Korean theaters and reached an annual audience of 76.5 million viewers - in a country with a total population of about 25 million. ${ }^{25}$

Several civilian American agencies actively facilitated the movement of Korean women into public life and encouraged the forging of cosmopolitan bonds with other women in the Free World. The State Department, for one, considered Korean women's assumption of "increasingly important positions outside the home" to be "a most healthy development." ${ }^{26}$ While the ranks of publicly prominent South Korean women were limited, the State Department sent a number of them to the 
United States for extended tours, including a group of high school principals in 1955, the writer Kim Mal-bong (known as the Pearl S. Buck of Korea) in 1955, and the journalist Chung Choong-ryang in 1960. As part of their grants, recipients wrote and spoke extensively about their experiences in America, educating other Korean women and suggesting ways that Korea could modernize along American lines. The State Department reported that Kim Mal-bong obtained materials for five novels during her four-month tour and published multiple articles about "the equality of women with men in American life." ${ }^{27}$

The Asia Foundation also targeted women and early on began funding women's associations, conferences, and leadership training programs. TAF president Robert Blum was particularly eager to develop a cosmopolitan perspective among Asian women. In 1954 he hired an American women's organization expert whose mission was "to arouse greater women's participation in civic affairs in one country and then encourage them to have links with activities of women's groups in several countries." Blum hoped this expert would stimulate "greater intra-Asian civic consciousness as well as generating greater mutual cooperation, respect and understanding among Asians themselves and Asians and Westerners." ${ }^{28}$ The Seoul office increased its attention to women under the leadership of Mary Walker, who in 1955 stepped in as acting representative after the sudden death of Philip Rowe and became the first woman to head a TAF office. Arriving from TAF's Tokyo office with the title of administrative assistant, Walker carried a double load of both programming and administrative duties. In 1956 she hired a local female consultant to produce "a good, objective survey of Korean women's activities and problems," and used her report to encourage "a substantial program of private activity in women's civic and community service groups." ${ }^{29}$

TAF's effortswere complemented by theCommitteeofCorrespondence-another "camouflaged" CIA-funded organization-whose mission was "to seek out and train women leaders" across the Free World and to help them "take their rightful places in the world." The Committee, which was launched in 1952 and run by a dozen women in New York, established a global network of letter-writing correspondents and hosted international women's workshops that facilitated engagement with the Free World. The first two workshops, held in 1956 and 1957, involved professional women and leaders from across Asia, many of whom went on to host additional workshops in their home countries. The Committee solicited the participation of educated Korean women and enabled them to forge connections to their counterparts in Asia, Africa, the Middle East, Latin America, Europe, and the United States. These initiatives increased Korean women's sense of themselves as members of a global community and fostered a cosmopolitan structure of feeling, one that Korean journalist Chung Choong-ryang described as a sentiment of "true friendship surpassing the national and racial boundaries." 30

None of these agencies was promoting a feminist agenda per se, and the furthering of US interests was always their ultimate objective. Yet their representations 
and activities intersected with a society in transition, at a moment when South Korean women were reimagining their social roles.

\section{COLD WAR COSMOPOLITAN FEMINISM}

The waging of the cultural Cold War and the promotion of modernization in South Korea were enabling conditions for the development of what I am calling "Cold War cosmopolitan feminism." Feminism is a capacious term that has meant different things at different historical moments. I am using it here to refer to a body of ideas and practices that critique women's systemic oppression under patriarchy, call for women's liberation, advocate for social and legal reforms, and identify and model alternative forms of womanhood. The idea of Cold War cosmopolitan feminism is a variation on Mire Koikari's "Cold War imperial feminism." Koikari, writing about postwar Japan, has explored how Washington's democratization efforts led to the expansion of Japanese women's legal rights in the 1947 constitution and beyond. For Koikari, the push for liberation from what Japanese feminists regarded as "feudal" constraints was inseparable from the assertion of US hegemony in East Asia and was thus continuous with older colonial discourses. ${ }^{31}$ While US occupation officials did not intervene so extensively in Korea's legal regulation of women, Korean feminists were likewise enabled by Cold War initiatives. These initiatives - which, as in Japan, were instrumental towards the achievement of US political objectives in Asia-legitimated local feminists' challenges to Confucian values and social structures. The notion of Cold War cosmopolitan feminism expands on Koikari's formulation by foregrounding the embrace by Korean feminists of internationalist discourses of universal rights and democratic freedoms; it also highlights how the Cold War facilitated Korean feminists' entrance into international networks of women.

At the core of Cold War cosmopolitan feminism is women's claim to the status of individual, and the conceptual linkage of that status to the noncommunist world beyond Korea's borders. Cold War liberalism validated the idea of women as autonomous human beings with identities distinct from their familial roles-a concept that is foundational to feminism, and deeply problematic within orthodox Confucianism. Like previous generations of reformers in Korea and across East Asia, postwar feminists looked outside the nation for ideals they needed to make changes within the nation. Feminism was thus closely intertwined with cosmopolitanism in the 1950s, and existed in some tension with a patriarchal cultural nationalism that was rooted in masculinist ideas of Korean essence.

Feminism and nationalism had developed interdependently in Korea, both fueled in part by Christian missionaries. Early nationalists in the 1890s-1910s had advocated for the reform of Confucian gender norms as an essential step in the creation of a modern nation-state, and early feminists had supported the nationalist movement as a move towards their emancipation. Yet as Hyaeweol Choi has 
shown, male intellectuals ultimately regarded women's concerns as secondary to national ones, and they ended up supporting a vision of modernity in which women remained subordinate to men and served the nation by tending to sons and husbands from within the domestic sphere. In the 1920s, this tension erupted into "head-on confrontations between vocal feminist women and male intellectuals," as educated New Women used their access to the public sphere to advocate for women's individuality and male intellectuals dismissed them "as selfish, bourgeois, and unpatriotic." According to Choi, colonial feminists' "emphasis on 'self' was discursively denigrated by androcentric and nationalistic discourses that privileged nation, family, and men." ${ }_{32}$ The challenge feminists posed to a male-centered social order was too profound to be easily accommodated. This tension erupted again in the 1950s, as postcolonial nationalists sought to restore what Chungmoo Choi has called Korea's "national masculinity." ${ }^{33}$

\section{HELEN KIM AND LEE TAI-YOUNG}

We can see articulations of Cold War cosmopolitan feminism in the lives of two of Korea's most prominent women-in-public: Helen Kim (Kim Hwallan), president of Ewha Womans University, and Lee Tai-young, Korea's first female lawyer. Kim and Lee were native modernizers who greatly expanded the possibilities for Korean womanhood. Both were mature New Women who came to consciousness of women's oppression in the 1920 and 1930s, survived the upheavals of the Korean War, and assumed positions of public authority in the late 1940s and 1950s. While these two middle-aged women often conformed visually to traditional gender norms by wearing hanbok and chignon hairstyles, they had achieved the goals of personal and professional autonomy that they had fought for as youth. More importantly, they used their unprecedented professional accomplishments to bring their longstanding calls for women's liberation into the mainstream. ${ }^{34}$ Claiming liberal ideals for Korean women, and finding support in Cold War institutions, they challenged the patriarchal Confucian family structure and the "traditional" values that undergirded it to claim new freedoms for Korean women.

Helen Kim (1899-1970) was one of the most influential Korean women of the twentieth century (figure 4). She shaped Korean society for decades as an educator, civic leader, and political actor. One of Korea's first feminists and a committed cosmopolitan, she saw herself as bound to other women both within and beyond the borders of Korea. Born in 1899 and raised as a Christian, Kim experienced a vision as a young woman in which God revealed "a big dug-out moat where a mass of Korean women were crying out for help with their hands outstretched from the haze and confusions that covered them." In the wake of this vision, she dedicated herself to "the emancipation of the women of the world." ${ }^{35}$ Kim was an early advocate of Korea's modernization, and like other feminists around the world she used the language of slavery to call attention to women's subjugation..$^{36}$ She graduated in 


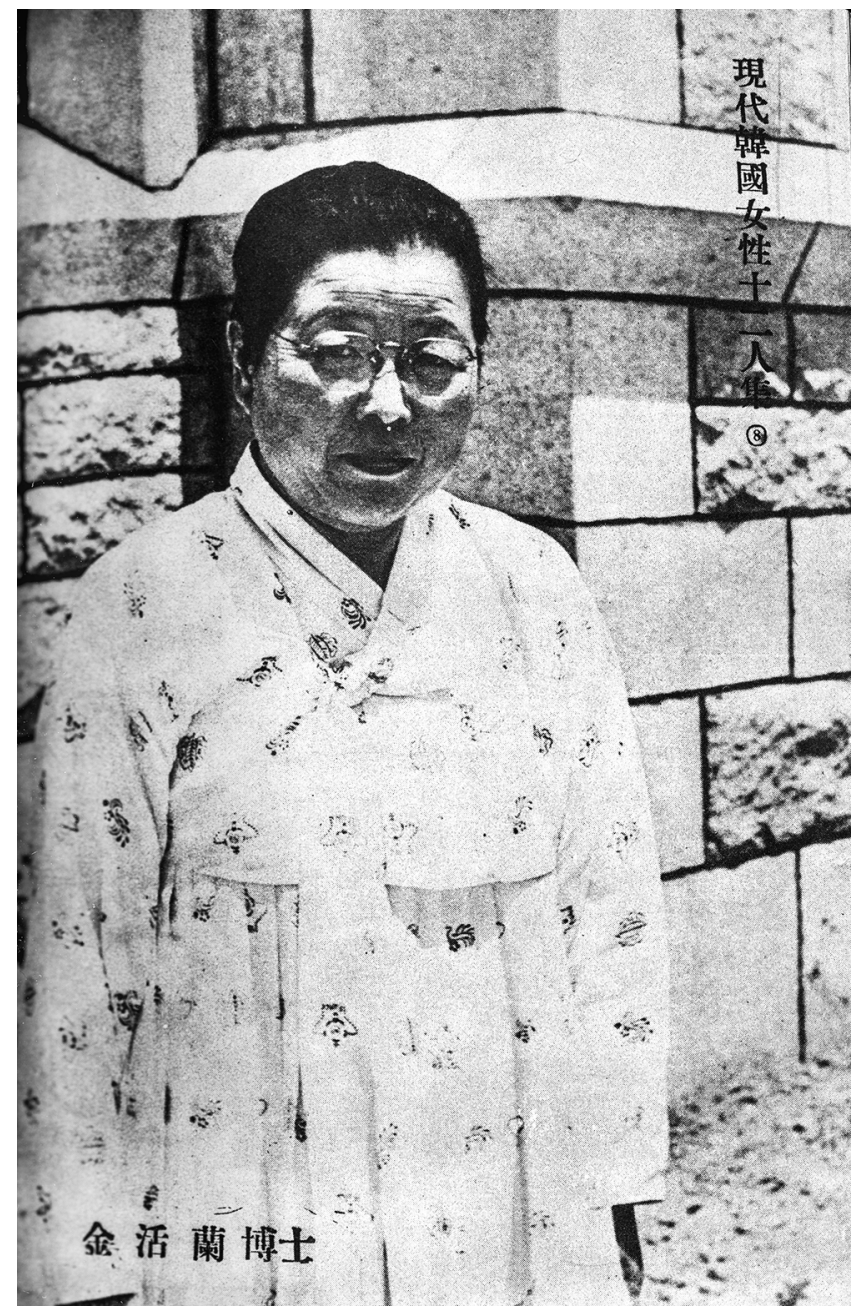

FIGURE 4. Helen Kim, president of Ewha Womans University, in the series “12 Modern Korean Women,” Yŏwŏn, August 1956.

1918 from the missionary-run Ewha Womans College, Korea's only institution of higher education for women, which Hyaeweol Choi has characterized as the "symbolic center for new womanhood." Kim notes in her autobiography that she was briefly active in the anticolonial nationalist movement of the 1910s, but she soon decided to focus her energies on women's education. ${ }^{37}$ She bobbed her hair, helped found Geunuhoe, one of Korea's first feminist organizations, and became a career woman when she took a teaching position at Ewha. Encouraged to study in the United States by her American female missionary teachers, she earned a bachelor's 
degree at Ohio Wesleyan University in 1924, a master's degree in philosophy at Boston University in 1925, and became the first Korean woman to earn a $\mathrm{PhD}$, from Columbia University's Teacher's College, in $1931 .^{38}$

Kim became a builder of women's institutions, nurturing organizations that put her emancipatory ideals into practice and gave them a solid foundation in society. She was a founder of Korea's first feminist magazine, Sin yoja (The modern woman), in 1920; organizer of the Korean branch of the YWCA in 1922; and the first Korean president of Ewha College in 1939, after Japanese colonial officials expelled American missionaries. After liberation in 1945, she served as advisor to the US military occupation government on women's education, ran for election to the Constitutional Assembly in 1948 to encourage women to exercise their new right to vote, and engineered the transition of Ewha from a college into Korea's first university. As president of Ewha Womans University, she significantly expanded women's access to higher education, physically enlarging the campus and increasing enrollment from just nine hundred students in 1945 to more than eight thousand in 1961, making it the largest women's university in Asia. Active in many arenas of public life, Kim served as a leader of numerous religious, political, and educational organizations, including the YWCA, the Red Cross, the Korean Association of University Women, and the Korean Christian Teachers' Association. Through these institutions, she enabled the higher education of thousands of women and facilitated their participation in public life. ${ }^{39}$

Helen Kim publicly promoted the radical idea of woman's selfhood. In the past, she said, "a young woman was considered a slave, a wife and a mother, but never an individual." Kim's goal at Ewha was "not only to educate so that women can take their rightful place in social, political and national life, but to establish their individuality." She took as her goal the "humanization of women," which meant helping them achieve their full potential as human beings unfettered by patriarchal constraints. Personally and professionally, Kim challenged the Confucian principles of female inferiority and submission. Defying her own father's authority, she rejected marriage and motherhood and chose a life of professional work and activism instead. ${ }^{\circ}$ Believing that marriage was incompatible with a career, she taught her students to choose one or the other and was known to express disapproval (as Jaesoon would do in Han's A Jealousy) whenever a particularly talented young woman chose to marry. ${ }^{41}$

Kim also apparently achieved what Jaesoon so fervently desired: a life partnership with another woman. After returning from the United States with her $\mathrm{PhD}$, Kim entered into what was known in America as a "Boston marriage": a long-term, committed relationship with a woman who shared her home and her life. Such "passionate friendships" among educated women were, like S-sisters in Korea and Japan, socially acceptable in late-nineteenth- and early-twentiethcentury America, and they were particularly common in elite women's colleges. ${ }^{42}$ Kim and her partner, Lee Jong Ai, had been students together at Ewha, although 
their relationship did not begin until Kim, a few years older, became a teacher there. Lee divorced her husband after an arranged marriage in which she suffered, according to Kim, "the typical unhappiness of Korean women," and with Kim's help got a scholarship to study nursing in Hawaii. (She would later attend Columbia University, also with Kim's help, to study nursing administration.) After her return in 1931 Lee moved into Kim's home. Lee took care of Kim's personal affairs even as she pursued her own career, enabling Kim to focus on her work, and her personal warmth reportedly offset Kim's often curt demeanor. They maintained a loving and devoted partnership_-what Kim called "a world of 'us"”-for thirty years, until Lee's death in $1954 .{ }^{43}$

Helen Kim participated in multiple distinct border-crossing networks. Her decision to accept the presidency of Ewha in 1939 enmeshed her in Japan's imperial network. Kim's feminism sometimes superseded her nationalism: she spoke out publicly in support of colonial rule and encouraged Korean women to seize the opportunities that the Japanese war effort presented, actions that in recent years have caused her to be branded as a collaborator and traitor. Like many colonial elites, however, Kim occupied a gray area in which the distinction between collaboration and nationalism was not always clear-cut, and as a feminist she often prioritized women's needs over a nationalism defined in patriarchal terms. According to Hyaeweol Choi, "collaborating with the (colonial) state was understood as a way to broaden the scope of women's work and influence." ${ }^{44}$ Kim's vision of female autonomy drew strength from her sustained engagement with the world beyond Korea's borders. She was the product of a missionary Christianity that transcended the colonial divide and that enmeshed women in global networks of faith and education. She traveled widely in Europe, Asia, Africa, and Latin America, experiences that gave her a sense of deep connection to "the whole world-past, present and future" and led her to believe in the existence of a "Woman's World" composed of capable women leaders from across the globe. ${ }^{45}$

In the 1950s, Kim put her cosmopolitanism in the service of the postcolonial nation. During Rhee's presidency, she became a regular facilitator of Korea's dialogue with the West, serving on numerous delegations to the United Nations beginning in 1949, working as director of the Office of Public Information during the Korean War, and in 1950 founding The Korea Times, an English-language daily newspaper aimed at US forces in Korea. As she had during the Pacific War, she hailed the Korean War as a modernizing force for women, one that would enable them to "abandon old customs and ideas" and become, in her word, "cosmopolitans." 46

Helen Kim was likewise enmeshed in transnational Cold War networks, both US- and Korea-centered. Americans regarded her as an ally in the dual projects of nation building and bloc building, and several US institutions underwrote her work. Kim had a close relationship with the Asia Foundation. Blum, who appreciated "the very energetic way" in which she cooperated with TAF's mission, dined 
at Kim's home when he visited South Korea in 1956, and Kim, in turn, awarded an honorary Ewha doctorate to TAF representative Mary Walker. ${ }^{47}$ TAF supported numerous organizations under Kim's leadership. It financed a program to train female "professional leaders" to run rural branches of the YWCA and provided funds for women associated with Kim's organizations to travel across the Free World; she, in turn, served on the board of the Social Science Research Library, a major TAF initiative. ${ }^{48}$ The USIA featured Kim in Free World magazine, its highest-circulating publication in Asia, lauding her as a "feminist" who has "guided and inspired" Korean women for more than half a century. ${ }^{49}$ The Voice of America featured her in a 1954 radio program, giving her a bullhorn to proclaim that the Korean woman, who had traditionally held power only "within the four walls of her home," was now "proud to take [her] place alongside the men of Korea in rebuilding their country." ${ }^{\circ}$ The Committee of Correspondence enlisted her as well, and Kim wrote numerous letters keeping women around the Free World abreast of developments at Ewha. ${ }^{51}$ Helen Kim put her feminism in the service of Syngman Rhee's transnational networks as well, working with the Asian People's Anti-Communist League (APACL), which pledged to "mobilize all freedom-loving women against communism." ${ }^{52}$ Kim served as vice-chair of the Korean branch of the regional organization, attended the planning meeting for the second annual conference in Manila in 1956, and that same year served as vice-chair of the APACL-sponsored Asian Youth and Students' Anti-Communist Conference in Seoul..$^{53}$ This latter conference required 40 percent of the delegates to be women and hosted a women's committee that called attention to women's lack of equality across Korean society. ${ }^{54}$ In all these capacities, Kim's cosmopolitanism combined with her nationalism: she made South Korea visible to other members of the Free World, even as she worked to transform South Korea in keeping with Western standards of social modernization.

Lee Tai-young (1914-98), South Korea's first female lawyer and a close friend of Kim's, spearheaded the public conversation about Korean women's legal equality. She recognized that, to be truly accepted, women's claim to the status of individual needed to be secured in the domain of the law. Lee was an outspoken advocate for women's rights, and like Kim she was a colonial-era New Woman who reached a position of public authority in the 1950s. Born in 1914, Lee attended Ewha Womans College in the 1930s, where she studied under Kim and majored in home economics because, she said, she "wanted to liberate women from kimchee jars, beanpaste jars." 55 When her husband was jailed for anticolonial activities in the 1940s, Lee became her family's breadwinner, teaching at a girls' high school and selling handmade quilts on the street to keep her children and mother-in-law alive..56 After liberation she enrolled in the law school at Seoul National University, which had just opened its doors to women. As a law student, she challenged norms about a married woman's exclusive service to her family: a thirty-two-year-old wife, mother, and daughter-in-law, she gave birth to her fourth child during her second year 


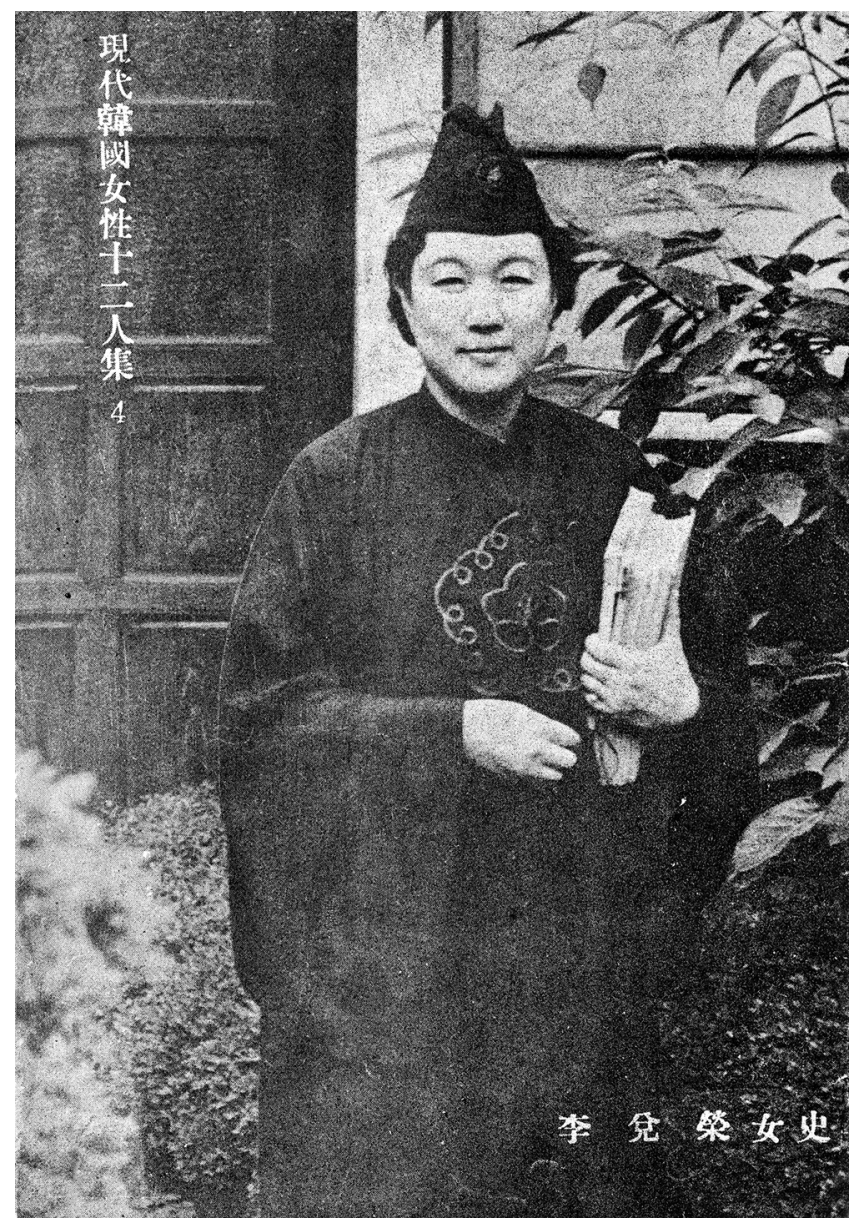

FIGURE 5. Lee Tai-young, Korea's first female lawyer, in the series " 12 Modern Korean Women," Yŏwŏn, July 1956.

of study and breastfed the baby between classes. In 1952, after sequestering herself away from her family to study, she became the first woman in Korean history to pass the bar exam and become a lawyer, a feat which landed her on the front page of the newspapers and prompted public celebrations at Ewha and elsewhere (figure 5). ${ }^{57}$ (No other Korean woman would pass the bar exam for nearly twenty years.) Like Helen Kim, Lee was an institution builder. When she submitted her application for a judgeship, Syngman Rhee summarily rejected it, asserting that "It is neither the time nor the place yet for a woman on the bench." (Lee's status as the wife of opposition politician Jeong Il-hyeong was also an issue.) Unbowed, Lee in 1956 established the Korea Legal Aid Center for Family Relations, Korea's 
first-ever legal aid clinic, in which she dispensed advice to what her biographer and coworker described as "an endless queue of Korean women waiting 5,000 years to find a woman lawyer who would listen to their stories and give them help." And like Kim, Lee participated prominently in public life: throughout the 1950s she gave lectures, taught at and served as dean of Ewha's College of Law and Political Science, and wrote newspaper and magazine articles and books on women's legal rights. Her activities were widely covered by the press, which alternately celebrated her achievements and mocked her vision of modern womanhood..$^{88}$

Lee Tai-young launched a sustained critique of the patriarchal family as the source of women's oppression and devoted her career to liberating Korean women from a system that rendered her a "slave" in her own home. Lee, like feminists around the world, embraced Norwegian playwright Henrik Ibsen's A Doll's House (1879) as a primer on modern womanhood. Ibsen's play became a touchstone in Korean debates about "the woman question" after being serialized in a daily Korean newspaper in 1921 (at the urging of the staff of Sin yoja, the feminist magazine of which Helen Kim was a founder) and staged for a public audience in Seoul in $1934 . .^{59}$ Nora, the play's heroine, is a bourgeois woman who comes to consciousness of her domestic entrapment and leaves her husband, children, and home for an uncertain future. The play charts the birth of an individual female self that is not defined by familial ties. A key exchange takes place at the end of the play, when her husband Helmer reminds Nora of her "sacred duties" to himself and her children. Nora, in perhaps the play's most famous line, responds that she has a duty "to myself" that is just as sacred: "I believe that before all else, I am a human being, just as you are." ${ }^{\circ 0}$ She then exits the house, closing the door behind her. This decision to prioritize her own needs over those of her family was a shocking-and for some, exhilarating-challenge to Confucian norms. Lee saw a universal truth in Ibsen's play. In a 1935 prize-winning speech delivered when she was a student at Ewha, Lee proclaimed that all Korean women were Noras:

If the first-generation doll is Ibsen's Nora, then the second-generation doll is the Korean woman. Korean women must break free of the halter of patient submission. To this day Korean women have not been treated as human. They have been slaves, nothing more than property, of husbands. Why should Korean women content themselves with this fate? This has been because they have long been soaked in traditions and customs. Women of Korea must break free of this halter immediately. Before they are wives and mothers, they must be human beings, and they must receive equal treatment as men. Others will not give this to you-each Korean woman must search for it.

Lee urged Korean women to liberate themselves from their role as "slaves," to throw off centuries of oppressive custom and claim their status as full human beings who are equal to men. She pushed Ibsen's feminist icon in a perhaps more radical direction when she went on to suggest that women, rather than leaving home, should 
remake it to satisfy their own needs: a Korean Nora should make herself "master of the home" by "chasing Helmer, her disrespectful husband, out of the house." ${ }^{1}$

In later years Lee, who claimed that "the real movement for the emancipation of women began only after the Liberation in 1945," celebrated the mass entrance of women into the workforce during the Korean War as "a great female revolution," because it awakened women to their economic power and stimulated their interest in attendant legal protections, and she praised working wives and mothers as "warriors doing battle in society." 62 Similar to Helen Kim in her "Boston marriage," Lee modeled an alternative form of womanhood to the Confucian norm by maintaining a companionate marriage with a man who encouraged her professional ambitions. She became a working wife and mother who challenged the boundary between public and private spheres by occupying both of them. Lee recognized that real reform of the family required a shift in consciousness among men as well as changes in the law, and she gave a pair of aprons, one trimmed in pink and the other in blue, as wedding gifts to her law students to remind them that a happy marriage was created when husbands and wives worked together, even washing dishes. ${ }^{63}$

In her focus on the legal regulation of the family, Lee carried the core concerns of the New Woman into the postwar era. Colonial-era New Women, arguing that arranged marriage was the lynchpin to the suppression of women's individuality in favor of familial interests, had advocated for a woman's right to choose her marriage partners ("free love") and her right of divorce. ${ }^{64}$ Lee's early activism focused on changing the adultery laws, which by holding only married women criminally accountable made possible the concubinage system, whereby married men could have multiple mistresses; the law was successfully revised in 1953 to hold married men and women equally culpable. ${ }^{65}$ Lee next brought the issue of divorce into public visibility, making it the subject of her first book, The Divorce System in Korea (1957). Similar to Helen Kim, Lee expanded the ranks of the modern woman when she educated thousands of women about their legal rights-and lack thereofwithin the patriarchal family structure.

Like Helen Kim, Lee Tai-young entered into Cold War transnational networks and received support from various US agencies. She sought and received the Asia Foundation's assistance in challenging the patriarchal family structure. The foundation deemed Lee's Legal Aid Center to be "a very active and promising" organization, one of only two that were "effectively working in the field of law," and in 1957-58 gave it a grant of several thousand dollars. The Foundation also made possible the publication of Lee's book on divorce through a grant of paper. ${ }^{66}$ The State Department, in turn, encouraged Lee's cosmopolitan consciousness by means of a leader grant, and in 1957-58 she spent six months in the United States as part of a delegation of lawyers from around the Free World who were studying and observing American legal work. While at Southern Methodist University in Dallas, Lee spent time with local feminist lawyers and legal activists; twenty years later she 
established a legal clinic in Killeen, Texas, for Korean women married to servicemen stationed at Fort Hood. Lee made an effort to turn the instruments of US propaganda towards her own ends, as when she arranged an interview with the Voice of America while she was in the United States in order to exhort Korean lawmakers to support her feminist legal reforms. ${ }^{67}$ She also belonged to the Committee of Correspondence and encouraged her graduate students studying law and international relations at Ewha to become correspondents as well. ${ }^{68}$ Engagement with these American institutions enhanced Lee Tai-young's and Helen Kim's status within Korean society, allowing their voices to be more widely heard and their organizations to function more effectively.

Lee's most ambitious legal campaign centered on the revision of the Family Law, the part of the civil code that applied to domestic matters. The head-of-family system (hojuje) was at the heart of the Family Law; imported from Japan during the colonial period and embodying five hundred years of Confucian principles, it cemented women's inequality and dependency by limiting their legal rights regarding marriage, divorce, inheritance, property, and legal status. Lee led the drive to revise the Family Law. Drawing on the cosmopolitan language of universal human rights and modern constitutional law, she argued that the head-of-family system deprived women of their full humanity as well as the equality guaranteed them by the 1948 constitution. Between 1954 and 1957 Lee organized a Federation of Korean Women's Groups (the members of which were closely tied to international women's organizations and included two groups headed by Helen Kim) that submitted a draft law to the National Assembly proposing the abolition of the head-of-family system and lobbied tirelessly for its passage. ${ }^{69}$

Their proposed reform of the family law triggered a heated debate about the nature of Koreanness and the best route towards postcolonial nation building. Lee and her compatriots argued that the recognition of women's legal rights as individuals constituted an essential step towards Korean democracy and modernity. They saw the head-of-family system as key to an antiquated Confucian tradition that must be shed in order for the nation to move successfully into the future. Lee railed against patriarchy as an "old, evil custom" and lambasted the "feudal family" as an "anachronistic" institution that perpetuated female suffering by inscribing "deep pain" in the "bones" of half the nation's population. ${ }^{70}$ Helen Kim's and Lee Tai-young's notion of Koreanness was forward- and outward-looking, grounded in a vision of a modern Korea that broadly embraced liberal Western norms, and they argued the case for legal reform from an internationalist perspective: if Korea was to join the world community as an equal member, it needed to uphold the principle of sexual equality throughout its legal system. As feminists, Kim, Lee, and the other members of the federation had something to gain from Cold War cosmopolitanism, which allowed them to assert a US-sanctioned ideal of Koreanness that was rooted in the ideals of democracy, modernity, and progress. 
Conservatives pushed back strongly against Lee's efforts by mobilizing a cultural nationalist discourse that privileged the very patriarchal values that the federation sought to eradicate. According to legal scholar Ki-young Shin, defenders of the existing law, which included orthodox Confucianists at the Institute of Confucianism and members of their national organization, Yudohoe, frequently couched their arguments within a discourse of "timeless tradition." Seeking to restore and purify the core values of authentic Koreanness that had been devalued by the Japanese during the colonial era and were now being eroded by the incursion of American values, they saw the preservation of the patriarchal family and the "fine, beautiful customs" (mip'ung yangsok) that upheld it as an essential part of the postcolonial nation-building project. They argued that the family, as the foundation of Korean society and culture, had to be protected from the encroachment of foreign ideas. According to Sangui Nam, the Confucianists saw the traditional family as a cultural asset that had to be preserved at all costs, and they campaigned vigorously against Lee's proposed reforms, organizing protests, threatening opponents, and warning that any change to the system of gender hierarchy would lead to the erosion of essential values. They also claimed that the proposed legal changes would open the door to same-sex marriage, stoking anxieties about lesbianism that would erupt in Han's A Jealousy. For these cultural nationalists, the patriarchal head-of-family system was an essential component of postcolonial national identity. Kim Byeong-ro, chief justice of the Supreme Court agreed and argued that the preservation of the Confucian family was the best way to restore the Koreanness that had been so tarnished under colonialism. ${ }^{71}$

While orthodox Confucianists were a distinct minority, the attachment to patriarchal ideals understood as essential national tradition was widespread. Historian Charles Kim has characterized the dominant attitude toward social change in the 1950 s as one of "postcolonial traditionalism." Produced by male intellectuals and aimed at young women, this vision of what Kim dubs "wholesome modernization" advocated the selective embrace of Euro-American practices in combination with the preservation of indigenous lifeways. It sought to eliminate Confucianism's worst abuses while preserving its "fine, beautiful customs" as the foundation of Korean identity. At the heart of those customs lay a conservative vision of Korean women as virtuous exemplars who should maintain the "wise mother, good wife" domestic ideal of generations past and thereby create the foundation for a wholesome society. While the discourse of wholesome modernization distanced itself from "hidebound" orthodox Confucianism, it did extend into the future a fundamentally patriarchal vision of women and the family as the cultural heart of the nation..$^{22}$

Postcolonial traditionalism can be seen as an expression of what Partha Chatterjee has called anticolonial nationalism: the effort by colonized and formerly colonized people to define a nation that is modern yet culturally distinct from the 
West. According to Chatterjee, anticolonial nationalism divides the world into material and spiritual domains. The material domain is the world of economics and politics; it is populated by men who embrace Western practices in the name of modernization. The spiritual domain preserves the nation's distinct cultural identity. It is populated by women and the family, who serve as embodiments of national essence and bearers of a self-conscious tradition that defines a resolute difference from an external hegemonic power. Through this gendered separation of spheres, anticolonial nationalism creates what Chatterjee calls a "new patriarchy" that is distinct from both the traditional order and the Western family structure. The new woman of anticolonial nationalism "was to be modern, but she would also have to display the signs of national tradition and therefore would be essentially different from the 'Western' woman." For Chatterjee, the formation of an anticolonial “'national culture' was necessarily built upon the privileging of an 'essential tradition" borne by women and the family. In 1950s Korea, that essential tradition was frequently identified with the patriarchal family. ${ }^{73}$

The struggle between feminists and patriarchal cultural nationalists over the Family Law came to something of a draw by the end of the decade. The revision that was passed in 1958 and came into force in 1960 legally secured women's status as individuals who could own property, take legal action, and in other ways act independently of men; at the same time, it maintained the patriarchal headof-family system and maintained sexual inequality across various dimensions of family life. ${ }^{74}$ Lee Tai-young praised the new law as "a revolutionary change." ${ }^{75}$ She also spent the rest of her life fighting for further revisions. (The head-of-family system was not abolished until 2002, four years after her death.) While some gender norms eased over the course of the 1950s-widow remarriage gradually became thinkable, for example, and freely chosen "love" marriages more common-many of the foundational assumptions about female inferiority, self-denial, submissiveness, and chastity continued to carry considerable weight. Women continued to occupy inferior positions in their families even as they moved into the public sphere as students, workers, and consumers. ${ }^{76}$ The foundational Confucian principles regulating gender remained strong. Female suffering persisted. "Being a daughter-in-law," recalled one war widow bitterly, still entailed "being a servant who cooks and gives birth." 77

The tension between Cold War cosmopolitan feminism and postcolonial traditionalism helped mark the 1950 s as a distinct historical period within Korea's modernization..$^{78}$ During these years, the ideal of the Nora-like female individual who asserted her autonomy and claimed an identity that superseded her familial roles was promoted and contested with equal vigor. This tension suffused Korea's visual culture and contributed to the production of such richly ambivalent texts as Han Hyung-mo's A Jealousy. Han's film delivered to a mass audience the feminist critique of patriarchal marriage as a form of slavery for women and a roadblock to their professional ambitions. It also voiced the possibility of a committed, loving 
relationship between two women, a version of the Boston marriage that Helen Kim enjoyed with Lee Jong Ai. At the same time, the film contained these new possibilities by casting them as expressions of mental illness. In a masterful trick of mass-market filmmaking, Han's film gave voice to both feminist and patriarchal visions of postwar womanhood. 